\title{
Anisomycin injection in area CA3 of the hippocampus impairs both short-term and long-term memories of contextual fear
}

\author{
Jessica Remaud, ${ }^{1,2,3}$ Johnatan Ceccom, ${ }^{1,2,3}$ Julien Carponcy, ${ }^{1,2}$ Laura Dugué, ${ }^{1,2}$ \\ Gregory Menchon, ${ }^{1,2}$ Stéphane Pech, ${ }^{1,2}$ Helene Halley, ${ }^{1,2}$ Bernard Francés, ${ }^{1,2}$ \\ and Lionel Dahan ${ }^{1,2,4}$ \\ ${ }^{1}$ Université de Toulouse (UPS), Centre de Recherches sur la Cognition Animale, 31062 Toulouse, France; ${ }^{2}$ Centre National de la \\ Recherche Scientifique (CNRS), Centre de Recherches sur la Cognition Animale, 31062 Toulouse, France
}

\begin{abstract}
Protein synthesis is involved in the consolidation of short-term memory into long-term memory. Previous electrophysiological data concerning LTP in CA3 suggest that protein synthesis in that region might also be necessary for short-term memory. We tested this hypothesis by locally injecting the protein synthesis inhibitor anisomycin in hippocampal area CAl or CA3 immediately after contextual fear conditioning. As previously shown, injections in CAl impaired long-term memory but spared short-term memory. Conversely, injections in CA3 impaired both long-term and short-term memories. We conclude that early steps of experience-induced plasticity occurring in $\mathrm{CA} 3$ and underlying short-term memory require protein synthesis.
\end{abstract}

\begin{abstract}
Memory formation is conventionally described by the succession of two steps. First comes a short-term memory that lasts a few hours and is independent of de novo protein synthesis; then comes a long-term memory, requiring the synthesis of new proteins (Davis and Squire 1984). Long-term potentiation (LTP) is a key mechanism for memory formation at the synaptic level (Bliss et al. 2006). Strikingly, LTP also displays a short-lived phase (termed early LTP) independent of protein synthesis, and a late LTP requiring de novo protein synthesis that lasts for months (Frey et al. 1993). Short-term memory is thus thought to rely on early LTP, while long-term memory formation would stand on late LTP (Kandel 2001). Importantly, the distinction between early and late LTP on the basis of the requirement for protein synthesis mainly relies on observations of LTP occurring at the Schaffer collateral synapses, corresponding to the CA3 pyramidal terminals onto area CA1 of the hippocampus (Malenka and Bear 2004). However, the mechanisms responsible for LTP can vary depending on the type of synapse considered. The properties of LTP occurring at the mossy fiber synapses, which are axon terminals given off by dentate gyrus granule cells and projecting to CA3 pyramidal neurons, are very different from the canonical LTP occurring at the Schaffer collaterals (Malenka and Bear 2004). In particular, some studies claim that LTP at mossy fiber synapses requires de novo protein synthesis from its initiation (BareaRodriguez et al. 2000; Hagena and Manahan-Vaughan 2013; but see Huang et al. 1994). Thus, protein synthesis seems to be required for LTP at the mossy fiber synapses, at least during its first hour. Given the putative aforementioned causal relationship between early LTP establishment and short-term memory formation, these observations indicate that protein synthesis should be required for the formation of any short-term memory relying
\end{abstract}

\footnotetext{
${ }^{3}$ These authors contributed equally to this work.

${ }^{4}$ Corresponding author

E-mail lionel.dahan@univ-tlse3.fr

Article is online at http://www.learnmem.org/cgi/doi/10.1101/Im.033969.113.
}

on the plasticity of the mossy fibers. Thus, the inhibition of protein synthesis in CA3 should impair short-term memory.

Contextual fear conditioning is a very common learning paradigm in which rodents have to quickly build a conjunctive representation of a context and to associate this context with an electric footshock. In this kind of declarative memory, the representation of the context is processed by the hippocampus while the amygdala is responsible for the association between the context and the aversive stimulus (Selden et al. 1991; Kim and Fanselow 1992; Phillips and LeDoux 1992; Barrientos et al. 2002). Hippocampal computational models and theories have emphasized a unique function in memory for each hippocampal subregion, with the CA3 area acting as an autoassociative memory network and the CA1 area as a critical output structure (Rolls and Treves 1996). Using local injections of lidocaine in dorsal CA1 or CA3, we previously showed that CA3 is necessary for the rapid elaboration of a unified representation of the context while CA1 is rather involved in the consolidation process of contextual memory (Daumas et al. 2005). Contextual fear conditioning can also be impaired by specific mutations interfering with plasticity at the Schaffer collateral synapses on CA1 (Rampon et al. 2000) or at the recurrent collaterals or mossy fiber synapses on CA3 pyramidal neurons (Otto et al. 2001; McHugh and Tonegawa 2009). This strongly suggests that contextual fear conditioning requires LTP in both subregions of the hippocampus. Local injections of protein synthesis inhibitors into the dorsal hippocampus have been shown to induce deficits in long-term, but not short-term, contextual fear memory (Igaz et al. 2002; Motanis and Maroun 2012). However, experiments assessing the role of the protein

(C) 2014 Remaud et al. This article is distributed exclusively by Cold Spring Harbor Laboratory Press for the first 12 months after the full-issue publication date (see http://learnmem.cshlp.org/site/misc/terms.xhtml). After 12 months, it is available under a Creative Commons License (AttributionNonCommercial 4.0 International), as described at http://creativecommons. org/licenses/by-nc/4.0/. 
synthesis in the hippocampus mainly targeted the CA1 subregion. To our knowledge, the requirement for protein synthesis specifically in CA3 in contextual fear conditioning has never been assessed.

We hypothesized that, if protein synthesis is required for the early stages of mossy fiber LTP (Barea-Rodriguez et al. 2000; Hagena and Manahan-Vaughan 2013), then the inhibition of protein synthesis in CA3 should impair both short-term and longterm contextual fear memory. Conversely, since protein synthesis is not required for early LTP in CA1, its inhibition in this structure should only impair long-term memory.

Protein synthesis inhibitor anisomycin was injected bilaterally in dorsal CA3 immediately after a contextual fear conditioning (CFC) session, and short- or long-term memory was measured. The same experiment was performed in another group of mice with local injection taking place in CA1. Ten to $15 \mathrm{~d}$ before the conditioning, male $\mathrm{C} 57 \mathrm{BL} / 6 \mathrm{~J}$ mice (10- to 16 -wk old, obtained from Charles River) were implanted bilaterally with guide cannulae above CA1 or above CA3. Surgery for cannulae implantation and intracerebral anisomycin administration was performed as previously described in Artinian et al. (2008). The behavioral procedures for contextual fear conditioning and analysis of behavioral data were performed as described in Daumas et al. (2004). Briefly, contextual fear conditioning (performed using the Panlab s.l. Startfear 1.06 system) consisted of a single train- ing session with two trials, consisting of a tone ( $85 \mathrm{~dB}, 30 \mathrm{sec})$ associated with an electric shock $(0.7 \mathrm{~mA}, 2 \mathrm{sec})$, separated by an inter-trial interval (ITI) of $120 \mathrm{sec}$. Immediately after the training session, injectors were lowered through the guide cannulae and mice received $0.25 \mu \mathrm{L}$ of anisomycin $(100 \mu \mathrm{g} / \mu \mathrm{L})$ per side at a rate of $0.1 \mu \mathrm{L}$ per minute. Contextual short-term or long-term memory was tested in different groups of mice, respectively, $1 \mathrm{~h}$ or $24 \mathrm{~h}$ after training by measuring the percentage of time spent freezing during the exposition to the context previously associated with the shock ( $4 \mathrm{~min})$. Two hours later, mice were placed in a different context and the percentage of time spent freezing was measured $(2 \mathrm{~min})$ in order to evaluate nonspecific freezing and the degree of generalization of the fear to another context. Then, in that different context, the freezing induced by the presentation of the tone ( $2 \mathrm{~min}$ ) was measured in order to test for cued fear conditioning that is supposed to depend on the amygdala and should not be disturbed by intra-hippocampal injections. Animal surgery and experimentation were approved by the French Animal Care and Use Committee (MP 02/02/02/06). All experiments were performed in accordance with the European Communities Council Directive (86/609/EEC). Data were analyzed using two way ANOVA (treatment: $\mathrm{NaCl}$ or anisomycin; testing time: $1 \mathrm{~h}$ or $24 \mathrm{~h}$ after conditioning). After examination of coronal sections, 33 mice were considered correctly injected bilaterally in CA1 (Fig. 1A,B). As expected, the effects of anisomycin
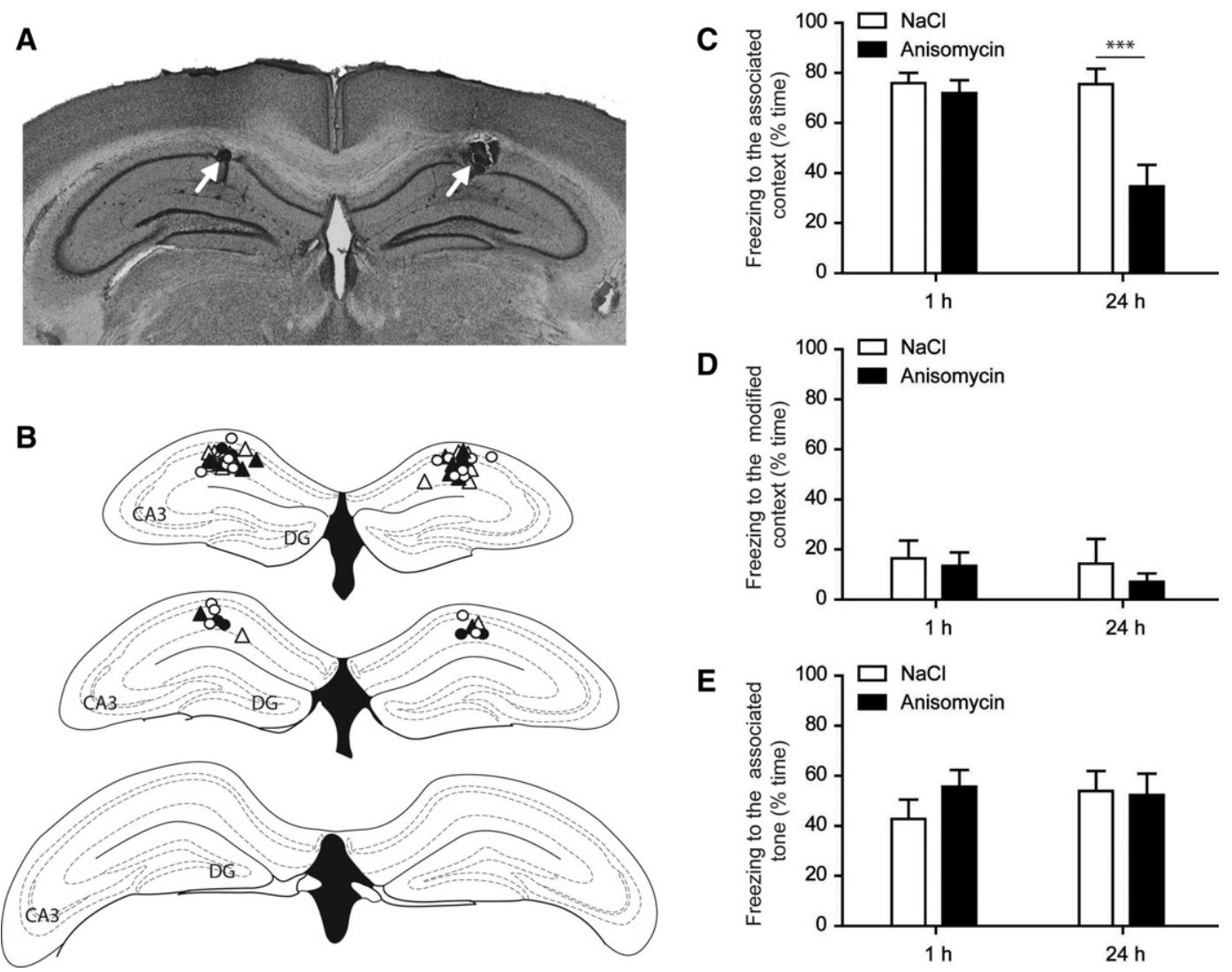

Figure 1. Anisomycin injection in the CA1 region of the hippocampus impairs long-term but not short-term contextual fear memory. $(A)$ Representative picture showing the location of injection sites (white arrows) in CA1. (B) Injection sites in CA1 for mice tested for short-term (triangles) or long-term (circles) memory. Open shapes correspond to saline injections while full shapes correspond to anisomycin injections. (C) One hour or $24 \mathrm{~h}$ after training, the percentage of time spent freezing was measured while mice were exposed to the context associated with the shock. Anisomycin injection impaired long-term but not short-term memory. (D) Freezing response to the exposure to a different context. All groups presented very low freezing levels to this context. $(E)$ Freezing response to the presentation of the tone previously associated to the shock. Anisomycin had no effect on the freezing related to the novel environment or to the tone. Sample size: $\mathrm{NaCl} / 1 \mathrm{~h}: 10$ mice; anisomycin/1 h: seven mice; $\mathrm{NaCl} / 24 \mathrm{~h}$ : eight mice; anisomycin/24 h: eight mice. $(* *) P<0.001$ for anisomycin vs. NaCl according to a Bonferroni post hoc test. 
injection in CA1 on the memory for the context were dependent on the testing time (treatment: $F_{(1,29)}=13.1, P<0.002$; testing time: $F_{(1,29)}=8.1, P<0.009$; interaction: $\left.F_{(1,29)}=8.3, P<0.008\right)$ (Fig. 1C). Bonferroni post hoc tests revealed that anisomycin injection in CA1 impairs long-term memory $(P<0.001$ for anisomycin vs. $\mathrm{NaCl} 24 \mathrm{~h}$ after conditioning), but not short-term memory $(P>0.05$ for anisomycin vs. NaCl $1 \mathrm{~h}$ after conditioning). There was no effect of anisomycin injection in CA1 on freezing levels measured in a different context (treatment: $F_{(1,29)}=$ $0.27, P=0.61$; testing time: $F_{(1,29)}=0.79, P=0.38$; interaction: $\left.F_{(1,29)}<0.001, P=0.98\right)$ (Fig. 1D) or when the tone was presented (treatment: $F_{(1,29)}=0.61, P=0.44$; testing time: $F_{(1,29)}=0.39, P=$ 0.54; interaction: $\left.F_{(1,29)}=0.98, P=0.33\right)($ Fig. $1 \mathrm{E})$, confirming a specific effect on contextual memory.

After examination of coronal sections, 39 mice were considered correctly injected bilaterally in CA3 (Fig. 2A,B). The effect of anisomycin injection in CA3 on the memory for the context was clear and significant, but this memory deficit was similar when tested $1 \mathrm{~h}$ or $24 \mathrm{~h}$ after conditioning (treatment: $F_{(1,35)}=89.3, P<0.0001$; testing time: $F_{(1,35)}=0.0003, P=0.99$; interaction: $F_{(1,35)}=5.42, P=0.026$ ) (Fig. 2C). Bonferroni post hoc tests show that the injection of anisomycin in CA3 induced a prominent deficit in both short-term and long-term memory $(P<0.001$ for anisomycin vs. $\mathrm{NaCl} 1 \mathrm{~h}$ and $24 \mathrm{~h}$ after conditioning) (Fig. 2C). There was no effect of the injection of anisomycin in CA3 on freezing levels measured in a different context (treatment: $F_{(1,35)}=1.35, P=0.25$; testing time: $F_{(1,35)}=$ 1.08, $P=0.31$; interaction: $\left.F_{(1,35)}=0.15, P=0.70\right)$ (Fig. $\left.2 \mathrm{D}\right)$ or when the tone was presented (treatment: $F_{(1,35)}=0.65, P=0.42$; testing time: $F_{(1,35)}=12.33, P=0.001$; interaction: $F_{(1,35)}=0.35$, $P=0.56$ ) (Fig. 2E), confirming a specific effect on contextual memory.

In order to confirm that anisomycin injection in CA3 was able to impair short-term memory, we tested the animals at the earliest possible time point. We ran a similar experiment in which mice were injected with anisomycin in CA3 immediately after contextual fear conditioning and tested for contextual fear 30 min after the training session. After examination of coronal sections, 15 mice were included in this experiment. Animals treated with anisomycin exhibited less freezing to the context than animals treated with $\mathrm{NaCl}$ ( $t$-test, $P<0.002$ ) (Fig. 2C). No difference was observed concerning freezing levels for a different context ( $t$-test, $P=0.21$ ) (Fig. 2D) or for the associated tone ( $t$-test, $P=$ 0.15 ) (Fig. 2E) when tested $2 \mathrm{~h}$ later. Altogether, these data show
A

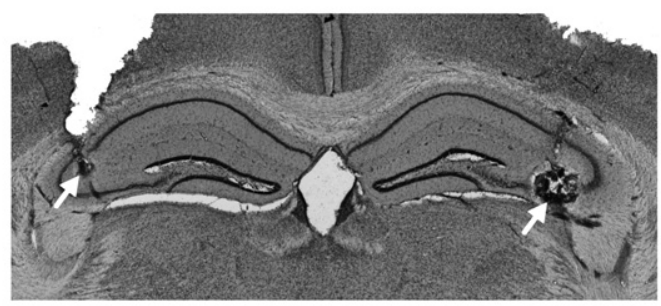

B
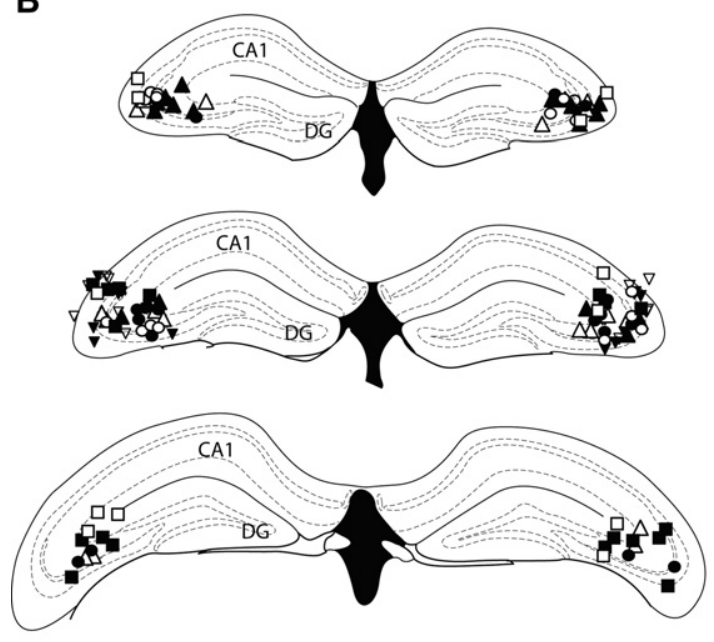

C

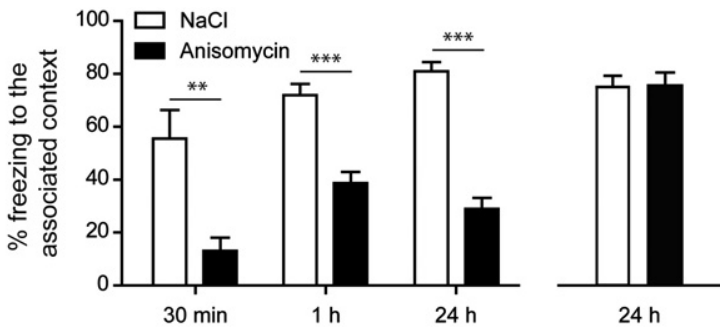

D

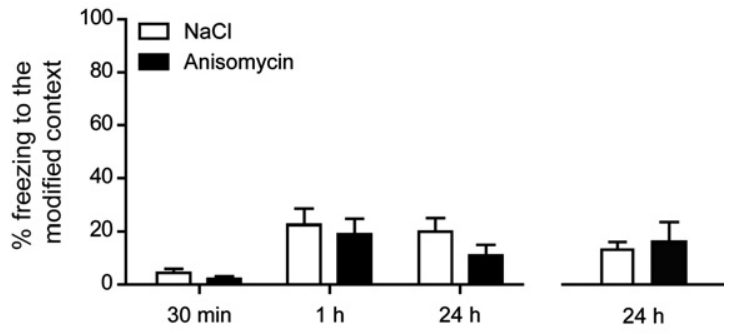

E

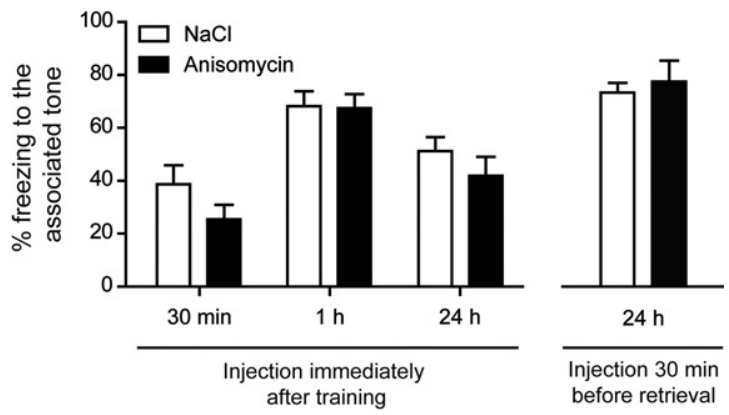

Figure 2. Anisomycin injection in the $C A 3$ region of the hippocampus impairs both long-term and short-term contextual memory but not retrieval. $(A)$ Representative picture showing the location of injection sites (white arrows) in CA3. (B) Injection sites in CA3 for mice tested $30 \mathrm{~min}$ (squares), $1 \mathrm{~h}$ (circles), or $24 \mathrm{~h}$ (upward triangles for injection after training, downward triangles for injections $30 \mathrm{~min}$ before retrieval test) after training. Open shapes correspond to saline injections while full shapes correspond to anisomycin injections. (C) Thirty minutes, $1 \mathrm{~h}$, or $24 \mathrm{~h}$ after training, the percentage of time spent freezing was measured while mice were exposed to the context associated with the shock. The local injection of anisomycin in CA3 immediately after the training impaired both long-term and short-term memory but had no effect when the injection was done 30 min before the retrieval session at $24 \mathrm{~h}$. (D) Freezing response to the exposure to a different context. All groups presented very low freezing levels to this context. $(E)$ Freezing response to the presentation of the tone previously associated to the shock. Anisomycin had no effect on the freezing related to the novel environment or to the tone. Sample size: $\mathrm{NaCl} / 30$ min: six mice; anisomycin/30 min: nine mice; NaCl/1 h: 10 mice; anisomycin/1 h: nine mice; NaCl/24 h: 10 mice; anisomycin $/ 24 \mathrm{~h}: 10$ mice; $\mathrm{NaCl} /$ retrieval: seven mice; anisomycin/retrieval: seven mice. $\left.{ }^{* *}\right) P<0.002$ and $\left({ }^{* * *}\right) P<0.001$ for anisomycin vs. NaCl according to a Bonferroni post hoc test. 
that anisomycin injection in CA3 impairs both short-term and long-term memories.

In order to determine if the freezing impairments observed at 30 and $60 \mathrm{~min}$ are due to a failure to form short-term memory or to disruption of retrieval, a separate group of mice was injected with anisomycin in CA3 $30 \mathrm{~min}$ before retrieval at $24 \mathrm{~h}$. After examination of coronal sections, 14 mice were included in this experiment ( $\mathrm{NaCl}, n=7$; anisomycin, $n=7$ ). In these conditions anisomycin did not alter the freezing $(P=0.93$ for the context, $P=0.71$ for the different context, $P=0.64$ for the tone). Thus, the injection of anisomycin in CA3 does not alter the retrieval of fear conditioning.

Here we show that anisomycin local injections in CA1 or CA3 do not affect contextual fear conditioning the same way. Injections in CA1 impaired long-term memory but had no effect on short-term memory. Conversely, the administration in CA3 impaired both short- and long-term memories. To our knowledge, this is the first study reporting an effect of protein synthesis inhibition in the hippocampus on short-term memory. This observation supports the idea that the early phase of synaptic plasticity occurring at mossy fiber terminals during contextual fear conditioning requires protein synthesis.

Control mice exhibited a prominent freezing behavior when placed in the context previously paired with the shock but not when placed in another context. Thus the freezing levels in the paired context specifically reflect memory of the context. Independent of the experimental conditions, the injection of anisomycin did not modify the freezing elicited by the tone previously paired with the shock. Similar results have been reported with different treatments interfering with the hippocampal function. This indicates that the hippocampus is involved in contextual memory while the freezing induced by the tone relies exclusively on an amygdala-dependent conditioning (Selden et al. 1991; Kim and Fanselow 1992; Phillips and LeDoux 1992; Daumas et al. 2004, 2005, 2009; Ceccom et al. 2013). This control experiment confirms that the local injections of anisomycin specifically blocked contextual memory while sparing other memory or cognitive systems.

Anisomycin injection in CA1 impaired long-term memory but not short-term memory. This result is consistent with previous studies using anisomycin local injections in the hippocampus that actually mainly targeted the CA1 area (Igaz et al. 2002; Motanis and Maroun 2012). The usual interpretation for these results is that short-term memory is due to protein synthesis-independent early LTP while protein synthesis-dependent late LTP supports long-term memory (Kandel 2001). Conversely, we demonstrated that anisomycin injected in the CA3 area impairs both short-term and long-term memory. Pyramidal cells of the CA3 area receive three main inputs: recurrent collaterals interconnecting CA3 neurons, temporo-amonic fibers arising from the entorhinal cortex, and mossy fibers coming from the dentate gyrus. Among these pathways, the mossy fibers are of particular interest when considering these results. On the one hand, the input of mossy fibers on CA3 plays a crucial role in contextual fear conditioning and is thought to participate in rapidly creating a conjunctive representation of a context (Otto et al. 2001; Daumas et al. 2004, 2009). On the other hand, protein synthesis inhibition blocks early LTP at mossy fibers while inhibiting only the late phase of the LTP occurring at the recurrent collaterals (Barea-Rodriguez et al. 2000; Calixto et al. 2003; Hagena and Manahan-Vaughan 2013). Thus, the most straightforward explanation for the effect of anisomycin on short-term memory is a blockade of the first stages of LTP at mossy fibers.

It is usually thought that new proteins necessary for LTP or memory are synthesized in the cell body of the neuron and then shipped to the synapse. Such a process seems too slow to account for a role of protein synthesis in short-term memory. However, activity dependent translation of preexisting mRNA can occur locally in the dendrites (Job and Eberwine 2001; Steward and Schuman 2001) within 5 min to 30 min (Ouyang et al. 1999; Tsokas et al. 2005). This quick time course is consistent with the observed short-term memory impairment and might explain why systemic injections of anisomycin after the training, which might not be quick enough to block the translation of preexisting mRNA, do not impair short-term memory (Bourtchouladze et al. 1998). Noticeably, the spines of the mossy fiber-CA3 hippocampal synapses contain a particularly large number of polyribosomes, allowing local synthesis of proteins necessary to the maintenance of LTP (Chicurel et al. 1993) and early maintenance of LTP at mossy fibers has been shown to rely in part on local protein synthesis as well as transcription-dependent mechanism in the soma of presynaptic neurons (Calixto et al. 2003).

Although most of the conclusions that were based on the use of protein synthesis inhibitors have been subsequently confirmed by molecular and genetic approaches (Hernandez and Abel 2008), serious concerns have been raised about the side effects of anisomycin. Notably, anisomycin is able to dysregulate monoamine release (Canal et al. 2007) or to inhibit the neuronal activity itself (Namgung et al. 1995; Sharma et al. 2012). Conversely, other studies showed that anisomycin was able to specifically block synaptic plasticity without interfering with neuronal activity (Frey and Morris 1998; Barea-Rodriguez et al. 2000; Karpova et al. 2006; Hagena and Manahan-Vaughan 2013). The discrepancies between these studies can be explained by the different doses used. Sharma et al. (2012) observed a strong inhibition of neuronal activity and synaptic transmission when using $50 \mu \mathrm{g}$ of anisomycin per hemisphere (or higher doses), while Barea-Rodriguez et al. (2000) observed a complete suppression of synaptic plasticity at mossy fibers without any effect on synaptic transmission per se by injecting a lower dose ( $12 \mu \mathrm{g} /$ side). In order to clarify this issue, Shires et al. (2012) recently tested the effect of different doses of anisomycin on synaptic transmission and plasticity. They showed that low doses ( 12 or $25 \mu \mathrm{g} /$ side) did not suppress neuronal activity but prevented long-term potentiation while higher doses $(62-500 \mu \mathrm{g} /$ side) clearly reduced the neuronal activity. It thus seems clear that when used at the appropriate dose, anisomycin is able to specifically block protein synthesis. Considering these data, we cannot rule out a possible nonspecific effect of anisomycin. However, we used a low dose of anisomycin $(25 \mu \mathrm{g} / \mathrm{side})$ and observed a differential effect depending on the injection area (CA1 or CA3). A previous electrophysiological experiment using similar doses showed a similar differential effect on synaptic plasticity (early LTP was affected only in CA3, late LTP both in CA1 and CA3) without any impairment of the neuronal activity per se (Barea-Rodriguez et al. 2000; Shires et al. 2012; Hagena and Manahan-Vaughan 2013). Thus, it seems reasonable to consider that protein synthesis inhibition is responsible for the observed behavioral effects of anisomycin injections.

Given the behavioral results presented in this study and given available data concerning synaptic plasticity in the hippocampus (Barea-Rodriguez et al. 2000; Otto et al. 2001; Calixto et al. 2003), we propose that protein synthesis in CA3 is required for the rapid elaboration of a unified representation of the context which involves LTP at mossy fibers. If this unified representation of the context is not built in CA3, it cannot be passed on to CA1 and memory is impaired from its very first stages.

In conclusion, this study shows that the rapid elaboration of a unified representation of a context requires protein synthesis specifically in area CA3 of the hippocampus. To our knowledge, it seems likely that the required protein synthesis occurs at the mossy fiber synapse on CA3 pyramidal cells and participates in the first molecular events underlying LTP at this peculiar synapse. 
However, we cannot completely exclude a possible nonspecific effect of anisomycin and additional work, identifying the proteins synthesized at the mossy fibers synapse following both LTP induction and contextual fear conditioning, is needed to strengthen this hypothesis.

\section{Acknowledgments}

We thank Clayton Dickson for helpful feedback on the discussion.

\section{References}

Artinian J, McGauran AMT, De Jaeger X, Mouledous L, Frances B, Roullet P. 2008. Protein degradation, as with protein synthesis, is required during not only long-term spatial memory consolidation but also reconsolidation. Eur J Neurosci 27: 3009-3019.

Barea-Rodriguez EJ, Rivera DT, Jaffe DB, Martinez JL. 2000. Protein synthesis inhibition blocks the induction of mossy fiber long-term potentiation in vivo. J Neurosci 20: $8528-8532$.

Barrientos RM, O'Reilly RC, Rudy JW. 2002. Memory for context is impaired by injecting anisomycin into dorsal hippocampus following context exploration. Behav Brain Res 134: 299-306.

Bliss TV, Collingridge GL, Laroche S. 2006. Neuroscience. ZAP and ZIP, a story to forget. Science 313: 1058-1059.

Bourtchouladze R, Abel T, Berman N, Gordon R, Lapidus K, Kandel ER. 1998. Different training procedures recruit either one or two critical periods for contextual memory consolidation, each of which requires protein synthesis and PKA. Learn Mem 5: 365-374.

Calixto E, Thiels E, Klann E, Barrionuevo G. 2003. Early maintenance of hippocampal mossy fiber-long-term potentiation depends on protein and RNA synthesis and presynaptic granule cell integrity. J Neurosci 23: $4842-4849$.

Canal CE, Chang Q, Gold PE. 2007. Amnesia produced by altered release of neurotransmitters after intraamygdala injections of a protein synthesis inhibitor. Proc Natl Acad Sci 104: 12500-12505.

Ceccom J, Bouhsira E, Halley H, Daumas S, Lassalle JM. 2013. Differential needs of zinc in the CA3 area of dorsal hippocampus for the consolidation of contextual fear and spatial memories. Learn Mem 20: $348-351$.

Chicurel ME, Terrian DM, Potter H. 1993. mRNA at the synapse: analysis of a synaptosomal preparation enriched in hippocampal dendritic spines. I Neurosci 13: $4054-4063$.

Daumas S, Halley H, Lassalle JM. 2004. Disruption of hippocampal CA3 network: effects on episodic-like memory processing in C57BL/6J mice. Eur J Neurosci 20: 597-600.

Daumas S, Halley H, Frances B, Lassalle JM. 2005. Encoding, consolidation, and retrieval of contextual memory: differential involvement of dorsal CA3 and CA1 hippocampal subregions. Learn Mem 12: 375-382.

Daumas S, Ceccom J, Halley H, Frances B, Lassalle JM. 2009. Activation of metabotropic glutamate receptor type $2 / 3$ supports the involvement of the hippocampal mossy fiber pathway on contextual fear memory consolidation. Learn Mem 16: 504-507.

Davis HP, Squire LR. 1984. Protein synthesis and memory: a review. Psychol Bull 96: $518-559$

Frey U, Morris RG. 1998. Weak before strong: dissociating synaptic tagging and plasticity-factor accounts of late-LTP. Neuropharmacology 37: $545-552$.

Frey U, Huang YY, Kandel ER. 1993. Effects of cAMP simulate a late stage of LTP in hippocampal CA1 neurons. Science 260: 1661-1664.

Hagena H, Manahan-Vaughan D. 2013. Differentiation in the protein synthesis-dependency of persistent synaptic plasticity in mossy fiber and associational/commissural CA3 synapses in vivo. Front Integr Neurosci 7: 10.
Hernandez PJ, Abel T. 2008. The role of protein synthesis in memory consolidation: Progress amid decades of debate. Neurobiol Learn Mem 89: $293-311$.

Huang YY, Li XC, Kandel ER. 1994. cAMP contributes to mossy fiber LTP by initiating both a covalently mediated early phase and macromolecular synthesis-dependent late phase. Cell 79: 69-79.

Igaz LM, Vianna MR, Medina JH, Izquierdo I. 2002. Two time periods of hippocampal mRNA synthesis are required for memory consolidation of fear-motivated learning. J Neurosci 22: 6781-6789.

Job C, Eberwine J. 2001. Localization and translation of mRNA in dendrites and axons. Nat Rev Neurosci 2: 889-898.

Kandel ER. 2001. The molecular biology of memory storage: A dialogue between genes and synapses. Science 294: 1030-1038.

Karpova A, Mikhaylova M, Thomas U, Knopfel T, Behnisch T. 2006. Involvement of protein synthesis and degradation in long-term potentiation of Schaffer collateral CA1 synapses. J Neurosci 26: 4949-4955.

Kim JJ, Fanselow MS. 1992. Modality-specific retrograde amnesia of fear. Science 256: 675-677.

Malenka RC, Bear MF. 2004. LTP and LTD: an embarrassment of riches. Neuron 44: 5-21.

McHugh TJ, Tonegawa S. 2009. CA3 NMDA receptors are required for the rapid formation of a salient contextual representation. Hippocampus 19: $1153-1158$.

Motanis H, Maroun M. 2012. Differential involvement of protein synthesis and actin rearrangement in the reacquisition of contextual fear conditioning. Hippocampus 22: 494-500.

Namgung U, Valcourt E, Routtenberg A. 1995. Long-term potentiation in vivo in the intact mouse hippocampus. Brain Res 689: 85-92.

Otto C, Kovalchuk Y, Wolfer DP, Gass P, Martin M, Zuschratter W, Grone HJ, Kellendonk C, Tronche F, Maldonado R, et al. 2001. Impairment of mossy fiber long-term potentiation and associative learning in pituitary adenylate cyclase activating polypeptide type I receptor-deficient mice. J Neurosci 21: 5520-5527.

Ouyang Y, Rosenstein A, Kreiman G, Schuman EM, Kennedy MB. 1999. Tetanic stimulation leads to increased accumulation of $\mathrm{Ca}^{2+}$ calmodulin-dependent protein kinase II via dendritic protein synthesis in hippocampal neurons. J Neurosci 19: 7823-7833.

Phillips RG, LeDoux JE. 1992. Differential contribution of amygdala and hippocampus to cued and contextual fear conditioning. Behav Neurosci 106: $274-285$.

Rampon C, Tang YP, Goodhouse J, Shimizu E, Kyin M, Tsien JZ. 2000. Enrichment induces structural changes and recovery from nonspatial memory deficits in CA1 NMDAR1-knockout mice. Nat Neurosci 3: $238-244$.

Rolls ET, Treves A. 1996. The hippocampus and memory. In Neural networks and brain function, pp. 95-135. Oxford University Press, Oxford, UK.

Selden NR, Everitt BJ, Jarrard LE, Robbins TW. 1991. Complementary roles for the amygdala and hippocampus in aversive conditioning to explicit and contextual cues. Neuroscience 42: 335-350.

Sharma AV, Nargang FE, Dickson CT. 2012. Neurosilence: profound suppression of neural activity following intracerebral administration of the protein synthesis inhibitor anisomycin. J Neurosci 32: 2377-2387.

Shires KL, Da Silva BM, Hawthorne JP, Morris RG, Martin SJ. 2012. Synaptic tagging and capture in the living rat. Nat Commun 3: 1246.

Steward O, Schuman EM. 2001. Protein synthesis at synaptic sites on dendrites. Annu Rev Neurosci 24: 299-325.

Tsokas P, Grace EA, Chan P, Ma T, Sealfon SC, Iyengar R, Landau EM, Blitzer RD. 2005. Local protein synthesis mediates a rapid increase in dendritic elongation factor $1 \mathrm{~A}$ after induction of late long-term potentiation. J Neurosci 25: 5833-5843.

Received November 25, 2013; accepted in revised form April 8, 2014. 


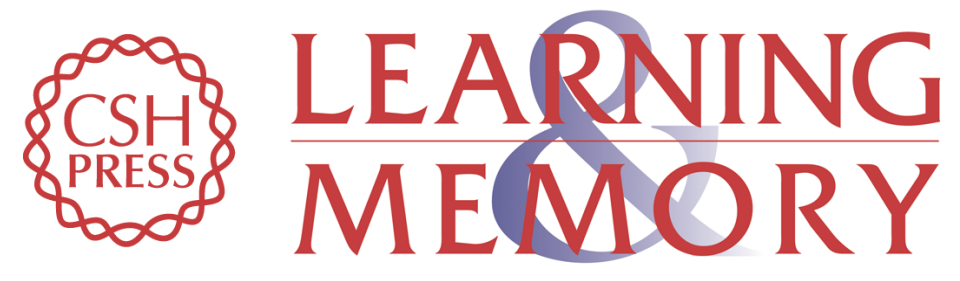

\section{Anisomycin injection in area CA3 of the hippocampus impairs both short-term and long-term memories of contextual fear}

Jessica Remaud, Johnatan Ceccom, Julien Carponcy, et al.

Learn. Mem. 2014, 21:

Access the most recent version at doi:10.1101//m.033969.113

\begin{aligned} & \hline References $\begin{array}{l}\text { This article cites } 36 \text { articles, } 18 \text { of which can be accessed free at: } \\ \text { http://learnmem.cshlp.org/content/21/6/311.full.html\#ref-list-1 }\end{array} \\ & \begin{array}{c}\text { Creative } \\ \text { Commons } \\ \text { License }\end{array} \begin{array}{l}\text { This article is distributed exclusively by Cold Spring Harbor Laboratory Press for the } \\ \text { first } 12 \text { months after the full-issue publication date (see } \\ \text { http://learnmem.cshlp.org/site/misc/terms.xhtml). After } 12 \text { months, it is available under } \\ \text { a Creative Commons License (Attribution-NonCommercial } 4.0 \text { International), as } \\ \text { described at http://creativecommons.org/licenses/by-nc/4.0/. }\end{array} \\ & \begin{array}{c}\text { Receive free email alerts when new articles cite this article - sign up in the box at the } \\ \text { top right corner of the article or click here. }\end{array} \\ & \begin{array}{l}\text { Service } \\ \text { terting }\end{array}\end{aligned}$ 